\title{
CANADIAN GHOSTS AND THE WILL TO TRUTH: READING MARLENE NORBESE PHILIPS' LOOKING FOR LIVINGSTONE
}

\author{
By Concetta Principe (YORK UNIVERSITY)
}

While the ghost may be a device for resolving past issues in literature, its presence in the archive is central to Derrida's critical approach in Archive Fever. Presenting this paper at an international colloquium "Memory: The Question of the Archives" at Freud's own archive, Derrida considers Yerushalmi's dialogue with the ghosted Freud as the desire that drives the archive: “... hauntedness is not only haunted by this or that ghost,... but by the spectre of the truth which has thus been suppressed" (Derrida 1998: 87). For Derrida, truth is a trace as elusive as "ash," untouchable but always recognizable in its absence, enforcing the Freudian trust in memory as true in part, the search for which, Derrida claims, inspires a sort of illness; thus, the fever of the archive. Derrida recognizes that remembering and repeating are central to the archive as an injunction to bear witness to the past which, according to Derrida, is a responsibility not to those who have passed, but for those who will read in the future. ${ }^{1}$ Nietzsche's understanding of the will to truth as that which perpetuates the assumption that truth exists can be understood as implicit to the endlessly repeated aporia of Derrida's ghost (Nietzsche 1956: 288). This spectre is made visible by the will to truth of a witness for specific future time and place.

In the same way that Derrida considers Yerushalmi's dialogue with the ghost of Freud, I will consider The Traveller's hunt for and dialogue with the ghost of the nineteenth century explorer, David Livingstone, in Marlene Norbese Philip's novella Looking for Mr. Livingstone: An Odyssey of Silence. Ostensibly standing as a post-

\footnotetext{
${ }^{1}$ Giorgio Agamben's definition of the witness most poignantly describes the injunction Derrida discusses: the one who bears witness for the one who cannot bear witness to herself/himself. Remnants of Auschwitz: The Witness and the Archive. Translated by Daniel Heller-Roazen. New York: Zone Books, 2002.
} 
colonial critique of British Imperialism, and motivated by an injunction to make restitution for past injustices against the African people, this novella ironically embodies a Derridian self-consciousness in its desire to bear witness. If we accept Derrida's ghost as the will to truth of the witness, the questions I pose in this paper are the following: what of the ghost in this novella is quintessentially Canadian; and having determined that, what part of truth is legible?

The title introduces the impossibility of the archive that Norbese Philip explores. The figure, David Livingstone, was hailed by his contemporaries as an astronaut of the African continent. Taking this metaphor as a premise, Looking for Mr. Livingstone: An Odyssey of Silence is a fabulous story referencing Stanley Kubrick's science fiction film 2001: An Odyssey, which referenced the ancient Greek epic by Homer, The Odyssey. By virtue of being language, the "silence" of Norbese Philip's odyssey forces a falsehood, and insofar as the title is true, which has bearing on the content, it cannot be iterated. This contradiction introduces what proves to be an unresolvable dilemma throughout the Traveller's journey. The Traveller is hunting for Mr. Livingstone to bring him to trial for the crimes he committed as an explorer. Her journey is defined by fantastic notions of time in which years are in the thousands; The Traveller's time is not our time; The Traveller's journey is “elsewhere," perhaps the place where iterations can be both silent and spoken. The tension between this nowhere and beyond time contextualizes how The Traveller can search for the dead British explorer, who, in the name of Imperialism and Christianity, had discovered, conquered, and converted the continent of Africa, and brought him to trial. His presence as the absent past turns this journey into a distant and fabulous tale of a far future. 
The continent of Africa where she hunts him as if he is an animal is depicted as fabulous and unmapped. As a result, the country which he conquered becomes an indefinite place in the text, making his conquest as fabulous a myth as The Traveller's journey is in search of him taking from the historical figure his victory. Ironically, this erasure dangerously minimizes the crime he must stand trial for: the silence which Livingstone raped from the continent. Each example of the rape of silence of the Africans whose culture was brutally taken from them bears witness to Livingstone's victims, and is therefore evidence for his crime. The truth that motivates her, to prove Livingstone was a liar and a racist, requires that she use the very language he used and as a result, she is implicated in his crime.

In the novella, "Silence" stands for all aspects of African culture, from artifacts to spirituality and language. Livingstone's actions as language "claim" to represent the violence done to that culture in the name of British Imperialism and God. In the novella, the Imperialists' violence is not unique, but has a precedent in an Eden-like time: "God first created silence...until one day man and woman lay down together and between them created the word. This displeased God deeply and in anger she took out her bag of words over the world, sprinkling and showering her creation with them. Her word store rained down upon all creatures, shattering forever the whole that once was silence" (Philip 2006: 11). Norbese Philip's God is not the Christian God because it is feminine, and one suspects it is not the God of one of the tribes, either. We can certainly say this God belongs to the novella because The Traveller's journey is built on the premise that words have done violence to sacred "silence," words which cut through the silence the narrator cherishes; a silence which she will find inside herself as her heritage. Norbese Philip's 
situating of violence in the word echoes Derrida's archive of language where the proper name is violence (Derrida 1998: 77).

During The Traveller's journey hunting down Livingstone, she is on a parallel journey discovering her cultural and spiritual inheritance of "silence" while living for a time with each of the seven "cultures" or peoples. These groups, mainly populated by women, are named with anagrams of the word "Silence." The SCENILE tribe gives her the anagram, "SURRENDER and WITHIN" which she uses at the end of her journey. With the CLEENIS she enters the sweat-lodge and finds her words: birth, death, and between them, silence. Imprisoned by the NEECLIS, she makes the multi-coloured quilt of her silence. Having met seven versions of Silence, she is able to appreciate the significance of "The Museum of Silence." Here she finds collected in one place the silences of six of the seven tribes with whom she has lived. She argues with the Museum's officials: "It is mine-ours-I challenged, to do with as we pleased—to destroy if we so wanted. They told me the silences were best kept there where they could be labeled, annotated, dated, catalogued" (Philip 2006: 57).

The violence the narrator might exact on the "silence" by destroying it if she pleases is a reaction to the violence done by the archive to the African culture itself. By turning "silence" into anagrams, she can show how, when taken out of its original context, the word is made meaningless which then elides the violence exacted. And yet, violence is done by the Imperialistic and scientific methods of making meaning by labeling and housing in a "climate controlled" environment what is as elusive as silence. In the words of this book, the "silence" encased in the museum has been stripped of meaning, and thus un-silenced. 
That silence can be labeled and put in boxes on display at all is ironic: this irony is compounded by the fact that anything sitting in a display case is, actually, silent. The meaning of silence is confounding and even deafening. Just as the Museum destroys silence by labeling and encasing it, so The Traveller's words render silence un-silenced. So when she speaks about the silence belonging to her and that she has the right to destroy it if she wants, we feel the impossibility of ownership since "silence" has been un-done by both the archive and her words. Every attempt made in this sequence to undo the initial violence done by Livingstone is undermined by the fact that she does violence with every word she uses. So what is the point? The un-naming of that which she names, played out on a variety of levels, turns the book into the site of witnessing the bare trace of truth. In this novella, language is the archive, each word is the site of both violence and the injunction to remember: without this violence, there would be no story; without the words, she could not own silence. In the process of using the colonizer's tool of language, she bears witness to the violence done to her heritage and takes back "silence" on behalf of her ancestors, while at the same time protecting the inherent value of "silence" in pure abstractness, the Freudian memory as part of truth, and thus to bring healing to the African continent.

The Traveller's work in the archive seems politically aligned with Verne Harris' article "The Archive is Politics," in which he argues that the archivist must be actively seeking justice for past crimes: “... every archivist is confronted by and must confront oppression and that the call of justice comes to every archivist" (Harris 2005: 123). Her work, though necessarily violent, is actually quite playful. She does this most emphatically in her dialogue with Mr. Livingstone, the ghost of the Imperial crime. 
Before she meets him, The Traveller encounters Mary, Livingstone's wife, through a letter, dated January 18, 1859. As fabulous as the rest of the book, this letter stands as prophetic since it is dated four years before her death of Malarial fever while with her husband on the Zambesi expedition. In this letter, we read of her husband's silence which is not enough for her; of her "howling silence"; of the "massive impenetrable and continental silence" of Africa, which her husband "penetrates" like a lover. With prescience of her death, she writes: "When the Silence of Shupanga claims me for the last time, David, you will weep for me and my silence, my very small silence that now flails at the larger Silence" (Philip 2006: 29). This letter, found by the Traveller a century after her death, stands as a textual ghost in Norbese Philip's archive, a silence which, though small, howls just as the larger one does. It is possible to consider that Livingstone is a devourer of silence: that Mary was, like Africa, devoured by him.

In Tim Jeal's Livingstone, which Philip references as her historical source for the novella, Livingstone was "not merely seen as a kind of Victorian astronaut but also as a saintly and entirely dedicated missionary" (Jeal 1973: 164). Jeal's book explores how Mr. Livingstone was a mythic figure: one created by the Royal Geographic society to put England on the map as a world power, then fueled by Livingstone's own vanity, and furthered again in 1869, when Henry Morton Stanley, journalist for the New York Herald, journeyed in search of Livingstone for a headline story. When Henry Stanley found Livingstone, he made history with the question, “Dr. Livingstone, I presume?” This journalist named Stanley becomes the figure by which The Traveller de-mystifies the "nearly a saint" astronaut Livingstone. She writes herself into this journalist's historical encounter by using Stanley's question, “Dr. Livingstone I presume?" and then shows 
Livingstone for the vain, racist, somewhat stupid, socially crippled, man she claims he was.

Livingstone's conquest of Africa was not, as he and the Royal Geographic Society claimed, a new discovery: the Portuguese had already discovered and even colonized the continent on a small scale. When The Traveller claims: "The Portuguese were there before you—", she is interrupted by his response, "Half-castes—not Europeans!” (Philip 2006: 66); “Bull-shit!” she retorts, and makes a case against Livingstone's classist and racist prejudices. These prejudices underscored how he explored the continent and treated the indigenous people and are revealed in his aversion to The Traveller when she asks for a kiss. On seeing his response, she goads him by saying she has done worse with him in her dreams: "He blanched even more, betraying the African sun" (73).

As a woman of the "dark continent" colonized by Livingstone, The Traveller decolonizes his ancient grip, finger by finger, on her and Africa by exposing his reputation was a fabrication of fraud and willful ignorance. She strips him of the mythic victories of discovery by delineating the facts of his violence; as a discoverer for the British Empire, bringing God to the heathens, he raped the country of its culture and spirituality and made it a servant to the Empire. In other words: "You captured and seized the Silence you found — possessed it. Like the true discoverer you were — dissected and analyzed it; labeled it—you took their Silence — the Silence of the African—and replaced it with your own — the silence of your word" (Philip 2006: 70).

She batters Livingstone with riddles he does not understand. He is a nineteenth century ghost, after all, a pre-modern positivist enlightenment explorer. We, the post- 
colonial reader, are privileged with knowing not just the answer, but what she means by the question. There is something underhanded in the Socratic method she uses, a method that keeps the questioner's authority of knowledge secure: the Nietzschian will to truth. I wondered why The Traveller enacted this Socratic role, until I realized that she was performing its limitations and showing the idiomatic limitations of the archive. What Livingstone-I-presume can never do is live outside of his time: he is a ghost. He cannot understand her post-colonial framework: he does not understand he has done anything wrong. Unfortunately, in the face of his sense of innocence, her authority and judgment are stalled.

In an effort to break this deadlock and to reach some sense of conclusion to this trial, The Traveller reduces Livingstone's culpability to a power-struggle of heterosexual relations: "Relax, Livingstone- - this is not about sex, but just think, your Word, and my Silence — matching frequencies so low, so precise only we could hear. Word and Silence - which of the two sent out the mating call, Livingstone, your Word or my Silence? Have you thought of that? Maybe this is about sex after all, Livingstone-Ipresume-what do you think?" (Philip 2006: 73). She will not let him off the hook, and she cannot go beyond him. The two figures, The Traveller-not-like-Stanley, and the Livingstone-I-presume, remain entangled till the end in the silence which The Traveller has craved like water in the desert of words of her journey: "I surrendered to the SILENCE within" (75).

The Traveller surrenders, but the story goes on with a post-script that identifies that what we have read is a book in the archive; the original diaries with maps and polaroids resting in this archive remain ambiguous in the end. The Traveller claims she 
gave everything to the one community not colonized by the museum of silence: the CESLIENS. The Chief Archivist and Librarian, William D. Boyd, another fiction of this novella, has the last word when his note claims that the original diary is in the Bodleian Library at Oxford University. The Traveller speaks of several diaries and the librarian speaks of one: the authority of author and archive is here, and throughout the book, undermined.

In an effort to bring justice to her African ancestors, Looking for Livingstone rewrites the historical record of Imperialist explorations in Africa by using the language of the colonizer to reveal historical violence. While depicting the contortions of the power struggle with authority and the authorial role, and even the abstract quality of the crime, this journal manifests a specific injunction to remember. Memory as a part of truth reflects the Derridian fever that overwhelms the context of this novella. In this story, Britain claims to keep The Traveller's true archive, and yet there is rumour that it does not. In this novella, language, as culture, is an archive that not only reflects the national product, but also maintains national identity by exerting control over other nations. While The Traveller has identified how British Imperialism used language to erase silence in Africa, the question that immediately registers for me is how is this story Canadian?

Norbese Philips is a Canadian citizen from Tobago and recognizes herself to be of African descent. While I can suppose the Canadian-ness in this text is related to the place of writing this story, and the place of citizenship, it is possible to see in the encounter with Livingstone, Canada's colonial origins in the British Imperialist commonwealth. A case can be made in seeing that The Traveller's story parallels the oppression of the Native Americans in Canada, except that would involve ignoring one of the few locatable 
facts in this story which points to the text's political intentions. Set in Africa, the story points to the black African oppression in the slave trade-or does it?

A historical review of African migration through slavery helps to pin-point where this novella stands in time. Canada is distinguished for being the destination of the slaves fleeing America during the Civil War in the nineteenth century, and also a place of immigration from many Commonwealth countries, including the Caribbean, into current time. Historically, the Caribbean had been colonized by European countries early in the renaissance period. France had control of Trinidad and Tobego, and ran plantations on Trinidad with a labour force of slaves from Africa. Tobego, on the other hand, remained uncultivated until the British conquered the island in 1793 and established sugar plantations. The slaves who worked these plantations were also African slaves. In 1838, the British abolished slavery in its colonies; freed, some Tobegan slaves settled as free people in the land where they had been slaves, and others migrated to larger islands.

Livingstone first entered Africa in 1841 during the mad competition with other European countries to conquer Africa, indicative of the British Imperial expansionist project. He was hailed by his countrymen as an evangelist, preaching the word of God to the heathens. He returned several times in his mission to map Africa for the British Empire, and to bring the ideals of British culture and society to the savage Africans. As The Traveller points out, Livingstone did not discover Africa; it had already been conquered in part long before by the Portuguese. Since their arrival during the renaissance, the Portuguese had been running a long and successful slave trade out of Africa, a trade which had essentially populated plantations in the European colonies and in the United States. While Livingstone "conquered" Africa after his own country had 
already righteously abolished slavery in the colonies, the Portuguese were continuing to round up Africans for sale in the slave trade.

If we recognize Philip's biography as a premise for The Traveller's search, significant aporias become evident in comparing Philips' ancestral origins with the time of The Traveller's investigation. It would seem that the Black African heritage which The Traveller's experience aims to reclaim predates Livingstone's arrival on the continent. In fact, in this journey, we are meeting descendants of her ancestors who remained while her own family was taken out of Africa for slavery. In remembering the exiled Black Africans through the imperialist faux scientist Livingstone, is Norbese Philip actually talking about the slave trade at all? Does The Traveller of our Canadian "now" hunt for this figure into the far future to show that Livingstone's claims to bring European Christian ethics to the savages was decades too late? In fact, I would argue she is speaking more profoundly of the British legacy in Africa of wiping out the African culture because they deemed it inferior to British systems of religion and science.

The British nation's desire to civilize the savages was tantamount to willful collusion with the European racist policies that justified slavery. The British enlightenment project, epitomized in Mr. Livingstone, maintained its concepts of racial and cultural superiority in comparison to the African people. Although the British abolished slavery because in the end they saw this practice was not Christian, this moral principle did not stop them from justifying having slaves to begin with. It is this contradiction which is revealed in Livingstone's blindness with regards to the Portuguese; for him, the Portuguese slave trade is invisible whereas their racial origin as "half-castes" distinguishes their inferiority. In Norbese Philips' rewrite, the astronaut 
Livingstone saw the African, unlike the Portuguese, as Kubrick's apes marveling at the great monolith that descends to them from outer-space. In Norbese Philip's telling, American filmmaker Kubrick's anti-imperialist politics is being exploited. I am left wondering what in this novella is Canadian.

This British Livingstone is not only an out-dated ghost; he is a blind ghost. In his righteous benevolence, he never bothered to see that slavery had been raping the country for centuries before he came to save the African from a godless life. Ironically, now that the continent had been depopulated, his religion was being used to erase the African culture because it was deemed primitive. Through Livingstone, The Traveller is writing as witness to the culpability of British Imperialism in European race supremacy. These principles are Canada's inheritance which is underscored by the poetic attention to the limitations of archival practice in the text; Canada's greatest archive, its language and especially its spelling practices, is British. This legacy permeates the novella's construction of The Traveller's return to her African culture. Where did she start from? What were the conditions of her exile from Africa? We do not know. The absence of particularities of her exile intentionally gathers Canada into the British Commonwealth, ironically suggesting the arbitrariness of modern citizenship.

From this “outsider”, outer-space, perspective, historically and culturally, Norbese Philips' identifies British blindness as gendered: Livingstone and the librarian, William Boyd. The Latter makes claims which are questionable; the former maps Africa with his Imperialist tools blind to the impact of his deeply ingrained race and class prejudices. In contrast to the male figures of Britain, Africa is represented by the different cultures 
which The Traveller encounters as women. In simple terms, we can read Britain as male and Africa as female. In this dichotomy, Mrs. Mary Livingstone stands out.

Alongside Livingstone, Mary stands for the Imperialist camp. She is different from him, however, because she can hear the great silence of Africa, a sensitivity which aligns her with the African women. It seems that she straddles both worlds: imperialism and the indigenous culture. As if to complement this collusion of race and gender, The Traveller identifies her mission with the American male journalist, Henry Morton Stanley. Stanley's search for the truth of what has happened to Livingstone is motivated to tell a story that will sell newspapers back in New York. His investigation encourages a fiction-making expedition in the name of truth telling; the divide between truth and fiction is the space across which Norbese Philip's text dances. In the same way that the archive is the repository of the persistently elusive truth of Derrida's archive fever in this novella, it is also the place for the machinations of the will to truth. That will to truth is visible in the asymmetry of Mary, an asymmetry which is disturbing.

In the novella, Mary has special status based on two counts: she shares a place of equality with the African women because of her gender; in regards to her race, however, Mary is different from these women. This difference, as I will show, is full of judgment. Mary's textual ghost which gives voice to women who have traditionally been silenced, (Mary and the African cultures) stands as an inserted document that can be heard to say that the British woman is less guilty than the British conquering male. If Mary is privileged over Livingstone in this portrait because she is a woman, the African silence is privileged over Mary's because she is not black. I see in the figure of Mary, like some residue behind the smoke, a gendered privileging of suffering, which includes her, and a 
racial privileging of suffering which excludes her. The presence of this ghost in the archive says: black women have suffered more than the white woman therefore black women deserve redress more than the white woman.

What would have been the political outcome had Philips represented Mary as equal to Livingstone, blinded and deafened by her religious and racial superiority to the African? That would have kept the dichotomy of victim and victimizer clear for readers, fully indicating which crimes required redress. I would argue that Mary's role in this novella is more provocative than that scenario would allow. In the world of the novella, Mary is not human nor is she even a speaking ghost like Livingstone; she is an artifact of a ghost from before her death prefiguring the terms of her death to come. In The Traveller's archive, Mary is an impossibility. In Norbese Philips' text, Mary is a literary construct which exposes, in partial transparency, the author's bias for African suffering. If Livingstone stands for willful blindness of race politics, Mary reveals, in negative, the black person's prejudice against white people.

In this novella, the imperative to bear witness to injustice raises up the toxicity of Imperialist dirt which, as Derrida pointed out, makes us sick. The Traveller's journey starts on the classical assumption that the "truth was not allowed to be called into question" (Nietzsche 1956: 289) and provokes it in the role of the Traveller/author as witness. Without The Traveller there would be no eighteenth century astronaut to watch and marvel at. The elusiveness of this encounter, and especially its constructed-ness, is represented by the Livingstone Polaroid. It is an impossible record of a ghost; without The Traveller's journal to identify it, this artifact of the encounter would be forgotten, a 
piece of plastic paper destined for the garbage, illegible, reflecting the unreliability of truth.

As a construction of the author's vision of crime, judgment and redress, the text is also witness to the profound aporia in witness' testimonies. This perplexity is epitomized in the artifact of Mary. In this object, Norbese Philips, a poet of African descent living in Canada, questions her own relationship to the truth by exposing how truth is manipulated, and manipulable. One could say that through the impossible ghosted voice of a white woman, Norbese Philips indicates why this book does not pretend to be objective like a documentary about the moral failures of British explorers or the practices at the Bodleian Library at Oxford University; this novella rewrites the British odyssey, as a woman-made artifact, a long poem that makes no pretense at stabilizing a trust in truth. 


\section{BIBLIOGRAPHY}

Agamben, Giorgio. Remnants of Auschwitz: The Witness and the Archive. Translated by Daniel Heller-Roazen. New York: Zone Books, 2002.

Derrida, Jacques. Archive Fever: A Freudian Impression. Translated by Eric Prenowitz. Chicago and London: The University of Chicago Press, 1998.

Harris, Verne. "The Archive is Politics." In The Power and Passion of Archives. Reuben Ware et. al. eds. Saskatchewan: Association of Canadian Archivists, 2005, pp. 113-125.

Jeal, Tim. Livingstone. London: Heinemann, 1973.

Nietzsche, Friedrich. The Birth of Tragedy and The Genealogy of Morals. Tranlsated by Francis Golffing. Garden City, NY: Doubleday\& Company, Inc., 1956.

O’Leary, Joseph Stephen. Religious Pluralism and Christian Truth, Edinburgh University Press, 1996.

Philip, Marlene Norbese. Looking for Livingstone: An Odyssey of Silence. Toronto: The Mercury Press, 2006. 